\title{
A Framework for the Selection or Design of Production Planning and Control Systems: A Case of Application
}

\author{
Marcos Buestán, Ph.D. ${ }^{1}$, Hendrik Van Landeghem, Ph.D. ${ }^{2}$, and María López, M.Eng. ${ }^{1}$ \\ 1Escuela Superior Politécnica del Litoral, Ecuador, mbuestan@espol.edu.ec, mflopez@espol.edu.ec \\ ${ }^{2}$ Ghent University, Belgium, hendrik.vanlandeghem@ugent.be
}

\begin{abstract}
Choosing and designing production planning and control systems are critical tasks because they provide the means to translate the corporate strategy into direct shop floor actions. However, it is not always easy to find the correct systems for an application. This difficulty occurs if the company does not present the necessary criteria for the system, in which case the expected benefits may not be achieved. This study proposes a framework to support the selection or design of a production planning and control system (PPCS) based on the current characteristics of a company. Using relevant parameters, companies are categorized and posteriorly evaluated, identifying the negative and positive relations between the company characteristics and the principles of the evaluated PPCSs. To test the proposed framework, we apply it to determine a suitable system for Ecuadorian small and medium-sized enterprises. Simplified drum buffer rope (S-DBR) approach is found to be a suitable PPCS, and the framework suggested some necessary enhancements to resolve potential weaknesses that could arise during the application of S-DBR.

Keywords- production planning and control systems, framework, PPCS selection, small and medium manufacturing enterprises, simplified drum buffer rope
\end{abstract}

\section{INTRODUCTION}

The selection or design of a production planning and control systems (PPCS) are considered one of the most crucial decisions that companies has to take in order to translate the corporate strategy into actions related to the planning and management of its resources [1]. However, determining a suitable PPCS for a company is a complex decision. One of the primary concerns is determining its applicability considering the market requirements and the operational characteristics of the company.

Precisely, it has been a topic highly remarked by several studies in the operations management literature. For instance, Tenhiala [2]) considers beneficial for organizations exploring previous implementation, the suitability of the selected PPCS and determine the expecting limitations of its applicability. Similarly, Olhager and Rudberg [1]) insist on the importance of the relationship between the PPCS selected and the market and manufacturing strategy and present the consequences of a substantial mismatch among them. This aim is consistent with the exposed by Stevenson et al. [3] who suggest that the detrimental in operational performance measures are directly associated to select a PPCS not suitable to the market and manufacturing strategy of the company. The critical consequences presented by the authors can be explained by the highly integrative character of PPCS with other functional areas on the company [4] and its notably impact with key operational measures such as work in process, lead

Digital Object Identifier (DOI):

http://dx.doi.org/10.18687/LACCEI2019.1.1.276

ISBN: 978-0-9993443-6-1 ISSN: 2414-6390 times or due date performance [4].

In this respect the present article proposes a framework aimed to collaborate with the selection or design of a PPCS according to the characteristics of the market and the operational features of the companies. Despite several characterizations and frameworks have been proposed, most of them focus in qualitative dimensions. The proposed framework includes quantitative dimensions that make necessary the collection and analysis of data related to the operational and demand characteristics of the firm.

Once characterized the company, the methodology evaluates the suitability of the PPCSs using weights, based on literature review, that score the relationship between the characteristics of the company and the principles of the evaluated PPCSs. For that our proposed methodology applies a discrete and non-linear scale that categorizes the relationships such as positive or negative.

In order to evaluate the proposed framework, we apply it to determine a PPCS suitable to the Ecuadorian small and medium-sized enterprises (SMEs) among the MRP, Kanban, Workload control (WLC) and Simplified drum buffer rope (S-DBR) approaches. Ecuadorian SMEs characteristics such as the lack of sophisticated IT systems [5] or a strong focus in maximizing short term opportunities [6] are shared with many industries in Europe and around the world. Consequently, the conclusions and findings obtained from the application of the framework could be easily applied to other industries that maintain similar characteristics.

Among the different evaluated approaches, S-DBR appeared as the most suitable to the Ecuadorian SMEs. This system has been recognized by its simplicity as a result of simple production planning and an increasing emphasis on the control of the execution [7].

We are conscious that it could be pretentious offering a total and definitive scheme for the PPCS selection. Consequently, this research could be considered just a contribution to the practitioners as a guide that suggest how a PPCS could be selected and adapted to the operational characteristics and market context of the companies.

The remainder of this paper is organised as follows. In section 2, a review of the literature and an analysis of the opportunities on existing frameworks for PPCS selection is presented. Section 3 describes each of the dimensions of our proposed framework according to the selected classifications. Section 4 presents the application of the proposed framework to the Ecuadorian SMEs. Finally, concluding remarks are provided in section 5 . 


\section{Production Planning And Control System SELECTion. A Literature ReVIEW}

\section{A. A Review of Proposed Frameworks for PPCS Selection} Initially an important group of authors present production system classifications. One of the primary objectives of these classifications was providing a tool to understand the characteristics of the complex production systems that facilitates their matching with respect to the properties of the different PPCSs [4]. The first classifications like the proposed by Schmitt et al. [8], Larsen and Alting [9] or Wysk and Smith [10] were primary focused on operational aspect giving limited attention to criteria like product characteristics or market requirements.

Future studies presented the highly linkage between these aspects and the design of the PPCS. For instance Volmann et al. [11] reports the strongly influencing of the market requirements and the product features with the PPCS design. Similarly, Hill [12] proposes the existence of a strongest link between the market requirements and manufacturing concerns. In this respect, some studies propose frameworks for PPCS selection that combines operational, market and product dimensions. For instance Hayes and Wheelwright [13] and Silver et al. [14] propose a classification of PPCSs that relates the process pattern with the level of product mix. MacCarthy and Fernandes [4] present an extensive classification that integrates process and product dimensions. Similarly, Vollmann et al. [15] establishes a framework that simultaneously includes process and market requirements.

\section{B. Opportunities Identified on Existing Classifications and Frameworks for PPCS Selection}

All the previous frameworks or classifications have been useful to obtain a better understanding of the true user requirements during the design or selection of PPCS. However most of the cases the included characteristics are limited to a few dimensions or composed exclusively for qualitative categories.

For instance, Hayes and Wheelwright [13] and Silver et al. [14] include just one product and one process qualitative dimensions as part of the framework for categorizing PPCSs. In the framework proposed by Vollmann et al. [15] despite market, product and process characteristics are included just a few qualitative dimensions of each category have been involved. It is similar to the methodology proposed by Gaury et al. [16] where additional to some process characteristics the market category is only represented with two dimensions and the product category is totally excluded of the analysis. At the framework proposed by Henrich et al. [17] despite some quantitative dimensions are included, most of them were related to the process and just a few were associated to the market. Tatsiopoulos and Mekras [18] propose an expert system where the selection of a PPCS applies a typology that uniquely includes product and process characteristics.

Probably, the proposal of Stevenson et al. [3] is an exception but it is not formally a framework but a discussion that includes elements of product, process and market requirements. Similarly, Howard et al. [19] propose a rulebase system that consists of 142 characteristics, 39 management concerns and 223 activities. Probably it is the framework with the highest number of dimensions, however its technological requirements make the application of this methodology highly limited for SMEs.

Based on the previous there is still a need for a framework that considering product, process and market dimensions combine a quantitative and qualitative approach.

\section{Framework fOr Selecting OR Designing Production PlANNING AND CONTROL SYSTEM}

The proposed framework is elaborated by combining market, product and process dimensions applied in classifications or methodologies that have demonstrated previously their usefulness. As other previous frameworks it still maintains a subjective component. However, a quantitative approach is reserved for dimensions where offering a too general or very superficial characterization could influence negatively in the selection. At all of the cases this study expects to offer a proper balance between the level of detail and the level of aggregation for each of the selected dimensions.

The proposed framework is composed of two parts. Initially a group of relevant dimensions selected according to the found in previous literature is used to characterize a company according to the market, product and process categories. Afterwards the possible PPCSs are evaluated by indicating if the PPCS "best-fit" to the description of the company for each of the characteristics included in the framework. As shown in Table I, a non-linear scale is applied marking each of the dimensions at a positive or negative score depending on the positive or negative relation of the characteristic of the company with respect to the principles of the PPCS.

A PPCS is more suitable for a company than others in the way that numerous characteristics of the firm support the principles of the PPCS. A description of each dimension and the reasons for its selection is presented in the following sections.

TABLE I

CATEGORIZATION OF THE POTENTIAL RELATIONSHIPS BETWEEN THE CHARACTERISTICS OF THE COMPANY AND THE PRINCIPLES OF PPCS.

\begin{tabular}{|c|c|c|}
\hline Score & Categorization & Description \\
\hline 9 & $\begin{array}{l}\text { Highly positive } \\
\text { correlation }\end{array}$ & $\begin{array}{l}\text { PPCS principles fit perfectly to } \\
\text { the company's characteristics } \\
\text { and influence significantly in the } \\
\text { achieving of its aims. }\end{array}$ \\
\hline 3 & $\begin{array}{l}\text { Some positive } \\
\text { correlation }\end{array}$ & $\begin{array}{c}\text { PPCS principles are in according } \\
\text { to the company's characteristics } \\
\text { and support the achieving of its } \\
\text { aims. }\end{array}$ \\
\hline 1 & Neutral & $\begin{array}{c}\text { The principles of PPCS are not in } \\
\text { conflict with the characteristics of } \\
\text { the company and does not affect the } \\
\text { accomplishment of its aims. }\end{array}$ \\
\hline-3 & $\begin{array}{l}\text { Some negative } \\
\text { correlation }\end{array}$ & $\begin{array}{c}\text { PPCS principles are not suitable to } \\
\text { the company's characteristics and } \\
\text { influence negatively in the achieving } \\
\text { of its aims. }\end{array}$ \\
\hline-9 & $\begin{array}{l}\text { Highly negative } \\
\text { correlation }\end{array}$ & $\begin{array}{l}\text { PPCS principles are opposite to } \\
\text { the company's characteristics } \\
\text { and jeopardize significantly the } \\
\text { achieving of its aims. }\end{array}$ \\
\hline
\end{tabular}

\section{A. Market Requirements Characteristics}


Probably the market requirements have been the category more extensively studied in the Operations Management (OM) literature with several studies presenting its relationship with the design of PPCS [1], [12]. According to authors like Schroeder [20] a mismatching between this category and a manufacturing strategy decisions such as the selected PPCS can affect significantly the performance of the manufacturing firm. For instance, a market requirement of maintaining a highly delivery reliability could determine that firms select a PPCS more oriented to a MTO approach. Similarly, depending on the market strategy firms could be more predisposed to a pull instead of a push PPCS.

The market dimensions included will be selected according to their level of influence presented in previous studies. A clarification is included for the dimensions just in case the name does not offer a clear meaning.

Order Winner: The orders winners can be considered the most direct representation that have the industries with respect to what the customer are expecting from them. They are the criterion used by companies to win order. According to Olhager and Wikner [21] companies usually does not focus in more than one of the following initiatives. We adopt the dimensions proposed by Jacobs and Chase [22]:
- Quality
- Price
- Delivery Speed
- Delivery Reliability
- Flexibility to cope with changes in Demand
- Flexibility for offering a wide variety of products

The Volume Demand Variability: The demand variability is considered by several authors a primary factor in the selection of a PPCS considering its serious consequences in the company's performance [23]. A highly demand turbulence could result in excess of inventory, stocks outs or elevated lead times.

Several authors express the demand variability through the calculation of the coefficient of variation (CV) of its volume demand [24]. This indicator that will be applied in this framework is aimed to show the consistency or discrepancy of the demand for a specific product in an established period. The $\mathrm{CV}$ should be calculated for a specific group of products that represent at least the $80 \%$ of the total sales considering their demand in several periods for one year. The level of variability is classified according to the following proposed categories:

- Low Variable Volume demand: At least $75 \%$ of the products present a $\mathrm{CV}<=0,75$.

- Moderate variable Volume demand: There are a considerable number of both low variable and high variable products. Additionally, in case that at least $75 \%$ of the products present a $\mathrm{CV}$ between 0,75 and 1,33 the system is considered moderate variable.

- High variable Volume demand: At least $75 \%$ of the products present a $\mathrm{CV}>1,33$.

The Inter Arrival Time Variability: Probably the quantitative approach of this measure has restricted its extensive applications in previous classifications. Uniquely, Henrich [25] proposes the inter arrival time variability (Ca) as part of a classification. However several authors presents $\mathrm{Ca}$ as the primary indicator of demand variability [26] [27] [2], a measure that characterizes the variability received by the production system. Our proposed framework adopt the classification proposed by Hopp and Spearman [28].

- Low Variable Arrivals: $\mathrm{Ca}<=0,75$

- Moderate variable Arrivals: $0,75<\mathrm{Ca}<=1,33$

- High variable Arrivals: $\mathrm{Ca}>1,33$

Due Date Tightness: Similar to the last dimension the due date tightness has not been extensively applied in previous frameworks. Proposed by Henrich et al. [17] it is a measure primary aimed to categorize companies that apply a MTO strategy. This measure is directly associated to the slack time of the orders that could be described as the remaining time between the finished expected time of the order and its due date [29]. In this respect, in case the slack time of most of the committed order is almost zero that environment can be categorized with high due date tightness. The proposed framework considers two categories that describe the level of due date tightness in a company.

- High due date tightness: Most of the committed orders present zero or almost zero slack time.

- Low due date tightness: Most of the committed orders present slack times that allow the insertion of orders.

Variability of Due Date Allowances: In order to include a detailed picture of the market environment additional to the average proposed by the due date tightness we require the inclusion of a variability indicator. Proposed by Henrich et al. [17] the variability of the due date allowances could be measured by calculating the $\mathrm{CV}$ of the orders' slack times $\left(\mathrm{C}_{\mathrm{sr}}\right)$.

- Low Variable Slack times: $\mathrm{C}_{\mathrm{sr}}<=0,75$

- Moderate Variable Slack times: $0,75<\mathrm{C}_{\mathrm{sr}}<=1,33$

- High variable Slack times: $\mathrm{C}_{\mathrm{sr}}>1,33$

Repetitiveness: Other dimension of the demand variability is the product mix variation described as variability in the proportion of the different products sold during a period. Several dimensions have been proposed for calculating this measure. Authors such as Steele [24] and Fisher and Ittner [30] suggest product mix indicators based on obtaining a $\mathrm{CV}$ of the product mix proportions or calculating the standard deviation of the number of options in a period of time respectively.

However, both measures require a high volume of information not necessarily available for all the companies. In this way, our proposed framework suggests the application of a measure that focuses on calculating the repetitiveness that could appear as a complement of the product mix variability. Proposed by MacCarthy and Fernandes [4], this indicator considers that a system is not variable when at least $75 \%$ of its products are repetitive. A product is repetitive when it consumes at least a $5 \%$ of the available production 
time. Maintaining the same scale than the proposed by MacCarthy and Fernandes [4] the dimensions are the following.

- Pure continuous system: Refineries

- Semi continuous system: Continuous systems with a combination of routes.

- Mass Production Systems: Almost all items are repetitive

- Repetitive Production System: At least $75 \%$ of the items are repetitive

- Semi repetitive System: A considerable number of repetitive and non-repetitive products.

- Non-repetitive production system: At least $75 \%$ of the products are not repetitive.

\section{B. Product Characteristics}

The product characteristics have been cited in previous bibliography as an important input to manufacturing strategy and consequently, an influential category in the design of a PPCS [1], [4]. Probably product issues such as volume or product mix have been the most widely discussed in previous articles. In fact, frameworks like the presented by Silver [14] combine exclusively volume and product standardization as the categories to determine the suitability of a PPCS for each category combination. At other cases like the categorization presented by Vollmann [11], the product dimensions are considered part of the market requirement category.

Level of Customization: The level of customization is a capability offered as part of the manufacturing strategy of many companies. Stevenson et al. [3] suggests that the level of customization has a direct impact on the variability of the product routings with a serious influence on the levels of inventory or cycle times. Additionally, a highly differentiation between one product and another reduces the parts commonality, making more complex the material requirement planning and reducing the stability and predictability on the demand. Based on the previous, it is clear that depending on the level of customization some PPCSs appear more suitable for a firm than others.

Mac Carthy and Fernandes [4] propose a classification that will be adopted in the framework proposed in this research.

- Customized Products: Clients design all the parameters of the product.

- Semi-customized: Client design part of the product design.

- Mushroom Customization: There are several standard products that are produced according to customer requirements.

- Standard Products: There is no intervention of clients in the product design.

Product Mix: The product mix is a dimension related to the level of variety of products elaborated in a company. At the frameworks proposed by Vollmann [31] or MacCarthy and Fernandes [4] they consider two levels of intensity: wide and narrow. Whereas, other authors like Silver et al. [14] proposes more level of detail by combining the product mix with the production volume. Precisely by considering it, a more complete dimension will be part of our framework.
- Custom: Few of each custom

- Many products: Many products elaborated in low volume

- Several major products: Several major products elaborated in high volume

- Volume commodity: Commodity products elaborated in very high volume

Product Structure: MacCarthy and Fernandes [4] are one of the few authors that established the product structure as an explicit category. It describes the complexity of the products in function of the number of levels in the Bill of materials (BOM). The inclusion of this dimension is in agree with the practice where the structure of the product can influence significantly in the a PPCS selection. The classification adopted in this framework is:

- Simple products: Products resulted of a mixing of chemical ingredients or the assembly of less than six components.

- Multi-level products: Products requiring assembly with numerous components.

\section{Process Characteristics}

One of the primary purposes of a PPCS is supporting the manufacturing strategy of a company [1]. Usually it resulted of the direct association with critical operational actions such the planning of materials, capacity management or the scheduling and sequencing of jobs on the shop floor [3]. For instance Kochhar and McGarrie [32] consider that process characteristics such as the number of manufacturing operations, the set up times or the degree of cellular manufacturing are key characteristics that should be related to the process for a PPCS selection. Similarly, Vollmann [31] presents characteristics such as the production layout, the process uncertainty and the flow pattern as critical characteristics of a process that should be considered during the PPCS selection.

Process Pattern: The process pattern is a recurring dimension in frameworks or classifications aimed to select a PPCS and described as one of the most determining factors in the analysis of the PPCSs applicability [1]. Mac Carthy and Fernandes [4] associate this dimension to the number and the similarity of the machines that conform the workstations. However, other frameworks like the proposed by Silver [14] or Stevenson [3] apply a more traditional approach directly related with the flow of materials on the floor. Precisely, this classification will be considered in our approach.

- Job shop: Routing sequences are random. There is a multi-directional and multi-stage processing.

- Batch Flow: The flow is jumbled, however more dominants paths emerge than at a job shop.

- Line Flow: Products flow from one operation to the next according to a fixed sequencing.

- Continuous automated, rigid flow: Product flow without stopping in the facility.

Production Information Availability: This dimension proposed by Larsen and Alting [9] is related to the characteristics of the information maintained with respect to the production process. Four different concepts are proposed 
for determining the characteristics of the information maintained.

- Accuracy: Detailed, General

- Volume: Few, plenty information

- Time: out to date, up to date

- Location of the information: Centralized, Decentralized

Level of Training: Human or behavioral criteria have been highly recognized as an important dimension during the design or selection of a PPCS [33]. The level of training or the type of skills developed on the shop floor operators can be more or less suitable to a specific PPCS. In this respect, this framework proposes two categories:

- Highly Skilled Operators: A considerable amount of intensive training has been provided to operators.

- Low Skilled Operators: Training of operators is deficient.

Processing Time Variability: This characteristic was suggested by Henrich et al. [17] as a category for exploring the applicability of WLC in SMEs environment. Similarly, numerous papers have applied this quantitative dimension for determining the performance of several PPCS in environments with different level of variability [34]. Our proposed framework adopt the classification proposed by Hopp and Spearman [28].

- Low Variability (LV): CV <0,75.

- Moderate Variability (MV): $0,75<=\mathrm{CV}<1,33$

- High Variability (HV): $\mathrm{CV}>=1,33$.

Set-up Time Correlation: Despite this dimension has been limitedly applied in other classifications, its influence with respect to the PPCS performance has been distinguished in previous literature. For instance, Schragenheim [35] presents the consequences of assuming a process where the sequence of work does not affect the capacity of the capacity constrained resource (CCR.) According to the author a sequence-dependent set-up could jeopardize the implementation of S-DBR suggesting DBR as a more suitable option in this case. We distinguish the following two types:

- Sequence-independent set-up times: When the sequence of work in a resource does not affect its capacity.

- Sequence-dependent set-up times: When the sequence of work in a resource affects its capacity.

\section{FRAMEWORK APPLICATION FOR SELECTION OF PPCS}

\section{A. Company Classification}

In this section we present the application of our proposed framework in order to determine a PPCS according to the characteristics of the Ecuadorian SMEs. The objective is to propose a general approach suitable to most of the companies included in this group.

This section characterizes Ecuadorian SMEs according to each of the 14 dimensions presented at our proposed framework. For that, we used the results of a survey developed to 117 SMEs and in-depth interviews to additional 17 manufacturing Ecuadorian SMEs. The results with respect to the classification can be found in tables II, III and IV.

TABLE II

MARKET CHARACTERIZATION OF THE ECUADORIAN SMES ACCORDING TO THE PROPOSED FRAMEWORK

\begin{tabular}{|c|c|}
\hline Market dimensions & Description \\
\hline $\begin{array}{l}\text { Order winner: } \\
\text { Delivery reliability }\end{array}$ & $\begin{array}{l}\text { Ecuadorian SMEs are principally MTO } \\
\text { companies with a particular interest in } \\
\text { maintaining a highly reliable due date } \\
\text { performance. }\end{array}$ \\
\hline $\begin{array}{l}\text { Volume demand } \\
\text { variability: MV } \\
\text { volume demand }\end{array}$ & $\begin{array}{l}\text { Based on the data proposed by the in-depth } \\
\text { interviews it was calculated the CV of the } \\
\text { primary products' demand. Results show a } \\
\text { CV from } 0,75 \text { to } 1.33 \text {. }\end{array}$ \\
\hline $\begin{array}{l}\text { Inter arrival time } \\
\text { variability: HV } \\
\text { arrivals }\end{array}$ & $\begin{array}{l}\text { Highly variability in quantity and timing of } \\
\text { the demand }\end{array}$ \\
\hline $\begin{array}{l}\text { Due date tightness: } \\
\text { High DD tightness }\end{array}$ & $\begin{array}{l}\text { The numerous competitors and the limited of } \\
\text { the market have made of the Ecuadorian } \\
\text { SMEs context a highly competitive } \\
\text { environment. In some cases, it implies } \\
\text { offering due dates that challenge the offered } \\
\text { by the competition. }\end{array}$ \\
\hline $\begin{array}{c}\text { Variability of due } \\
\text { date allowance: LV } \\
\text { slack time }\end{array}$ & $\begin{array}{l}\text { Most of the time the slack time of the orders } \\
\text { was very limited. The consistency of this } \\
\text { pattern in the long term was confirmed } \\
\text { through the coefficient of variation of a } \\
\text { sample of orders. Results present at almost } \\
70 \% \text { of the cases a CV }<0,75 \text {. }\end{array}$ \\
\hline $\begin{array}{c}\text { Repetitiveness } \\
\text { level: Repetitive } \\
\text { production system }\end{array}$ & $\begin{array}{l}\text { Despite Ecuadorian SMEs can be categorized } \\
\text { as MTO industries the customization is } \\
\text { usually leaved to the last stage of the process } \\
\text { in no more than two workstations. In this } \\
\text { way the semi-elaborated products consume a } \\
\text { significant percentage of the annual available } \\
\text { time. }\end{array}$ \\
\hline
\end{tabular}

TABLE III

PRODUCT CHARACTERIZATION OF THE ECUADORIAN SMES ACCORDING TO THE PROPOSED FRAMEWORK

\begin{tabular}{|c|c|}
\hline $\begin{array}{c}\text { Product } \\
\text { dimensions }\end{array}$ & Description \\
\hline $\begin{array}{c}\text { Level of } \\
\text { customization: } \\
\text { Mushroom } \\
\text { customization }\end{array}$ & $\begin{array}{c}\text { At almost all the MTO cases the product } \\
\text { differentiation was usually delayed as late as } \\
\text { possible in the process. }\end{array}$ \\
\hline $\begin{array}{c}\text { Product mix: Many } \\
\text { products }\end{array}$ & $\begin{array}{c}\text { Ecuadorian SMEs offer a wide variety of } \\
\text { products elaborated in low volume batches. }\end{array}$ \\
\hline $\begin{array}{c}\text { Product structure: } \\
\text { Simple products }\end{array}$ & $\begin{array}{c}\text { At almost all the cases the products' structure } \\
\text { is very simple composed by a mixing of } \\
\text { chemical ingredients or resulted of an } \\
\text { assembly of few components. }\end{array}$ \\
\hline
\end{tabular}

B. Production Planning and Control Systems evaluation

The proposed framework was evaluated contrasting the characteristic of the Ecuadorian SMEs with respect to the PPCSs approaches MRP, Kanban, WLC and S-DBR, using the non-linear scale shown in Table I.

Based on a critical assessment, the framework suggests S-DBR as the PPCS most suitable for the Ecuadorian SMEs' group. Despite many characteristics were considered suitable for the principles of S-DBR, the framework still present opportunities that can be overtaken incorporating mechanisms from other PPCSs where these dimensions were negatively evaluated as shown in Table V. In this way the framework not only assess the suitability of the evaluated 
PPCSs but also collaborate with the design of a customized solution based on the requirements of each firm. In the following sections is presented a detailed explanation of the reasons that come to the final score for each of the PPCSs under evaluation.

TABLE IV

PROCESS CHARACTERIZATION OF THE ECUADORIAN SMES ACCORDING TO THE PROPOSED FRAMEWORK

\begin{tabular}{|c|c|}
\hline $\begin{array}{c}\text { Process } \\
\text { dimensions }\end{array}$ & Description \\
\hline $\begin{array}{l}\text { Process pattern: } \\
\text { Batch Flow }\end{array}$ & $\begin{array}{l}\text { Preponderantly the products at the } \\
\text { Ecuadorian SMEs flowed with some } \\
\text { randomness but maintaining a dominant path } \\
\text { according to the elaborated families. }\end{array}$ \\
\hline $\begin{array}{l}\text { Production } \\
\text { information } \\
\text { availability: } \\
\text { General, few, out } \\
\text { to date and } \\
\text { centralized }\end{array}$ & $\begin{array}{l}\text { At Ecuadorian SMEs the system for } \\
\text { maintaining and analyzing production } \\
\text { information is precarious. It is reflected in the } \\
\text { in-depth interviews where } 34 \% \text { of the } \\
\text { companies not use any information system, } \\
34 \% \text { present an information system for } \\
\text { managing the production information but } \\
\text { isolated from the rest of the systems in the } \\
\text { company and just } 32 \% \text { has an integrated } \\
\text { information system for managing the } \\
\text { information. }\end{array}$ \\
\hline $\begin{array}{l}\text { Level of training: } \\
\text { Low skilled } \\
\text { operators } \\
\end{array}$ & $\begin{array}{l}\text { Only } 27 \% \text { of Ecuadorian SMEs offer training } \\
\text { regularly, it is more than three times per year }\end{array}$ \\
\hline $\begin{array}{l}\text { Processing time } \\
\text { variability: MV } \\
\text { processing time }\end{array}$ & $\begin{array}{l}\text { Elevated preparation times and long } \\
\text { breakdowns intervene in the increment of the } \\
\text { processing times, classifying it as moderately } \\
\text { variable (MV). }\end{array}$ \\
\hline $\begin{array}{l}\text { Set-up correlation: } \\
\text { Sequence- } \\
\text { independent set-up } \\
\text { times }\end{array}$ & $\begin{array}{l}\text { At least in } 80 \% \text { of the cases, the sequence } \\
\text { does not influence or has a very moderate } \\
\text { influence in the capacity. }\end{array}$ \\
\hline
\end{tabular}

Evaluating the MRP applicability in an Ecuadorian SMEs context: MRP is a system associated to software packages designed to manage high volume of information usually related to many products composed by numerous parts and subassemblies [36]. Precisely it is a non-critical characteristic in an environment where products are composed with few components like the presented in the Ecuadorian SMEs. Additionally, the application of MRP in an environment characterized by a frequent customization requires a constant generation of MRP-files [37]. Something that could be a challenge considering the lack of agility of the business processes in the Ecuadorian SMEs. Probably the unique positive point that supports a MRP implementation in the Ecuadorian SMEs context is the repetitiveness that distinguishes this market. Despite the variety of products, most of the capacity is employed in a reduced number of articles.

Traditionally, MRP has not been positively associated to MTO operational issues. One reason is its lack of ability to provide a proper planning in presence of variable shop floor routings [3] or the rigid assumptions related to fixed lead times [38]. The consequence is a system with an excessive sensitivity to changes not suitable to the agile and highly turbulent environment of the Ecuadorian SMEs. Additionally, MRP presents other important limitations to satisfy the requirement of the MTO sector in the Ecuadorian SMEs context. For instance, the lack of a customer enquiry stage for the due date determinations [3] or the ability to control the entry and release of the orders focusing on the due date performance (DDP).

TABLE V

FRAMEWORK APPLICATION CONSIDERING THE CHARACTERIZATION OF THE ECUADORIAN SMES

\begin{tabular}{|c|c|c|c|c|}
\hline $\begin{array}{c}\text { Ecuadorian SMEs } \\
\text { characterization }\end{array}$ & MRP & Kanban & WLC & $\begin{array}{c}\text { S- } \\
\text { DBR }\end{array}$ \\
\hline $\begin{array}{c}\text { Delivery } \\
\text { reliability }\end{array}$ & -9 & -9 & 9 & 9 \\
\hline $\begin{array}{c}\text { MV volume } \\
\text { demand }\end{array}$ & -3 & -3 & -3 & -3 \\
\hline HV arrivals & -3 & -3 & 9 & 9 \\
\hline $\begin{array}{c}\text { High DD } \\
\text { tightness }\end{array}$ & -9 & -9 & -9 & -9 \\
\hline LV slack time & 9 & 9 & 9 & 9 \\
\hline $\begin{array}{c}\text { Repetitive } \\
\text { production } \\
\text { systems }\end{array}$ & 9 & 9 & 9 & 9 \\
\hline $\begin{array}{c}\text { Mushroom } \\
\text { customization }\end{array}$ & -3 & -3 & 9 & 9 \\
\hline Many products & 9 & -9 & 9 & 9 \\
\hline Simple products & -3 & 9 & 9 & 9 \\
\hline Batch Flow & -3 & -3 & 9 & 3 \\
\hline $\begin{array}{c}\text { General, few, out } \\
\text { to date and } \\
\text { centralized }\end{array}$ & -9 & 9 & -9 & 9 \\
\hline $\begin{array}{c}\text { Low skilled } \\
\text { operators }\end{array}$ & -9 & 9 & -9 & 9 \\
\hline $\begin{array}{c}\text { MV processing } \\
\text { time }\end{array}$ & -3 & -3 & 9 & 3 \\
\hline $\begin{array}{c}\text { Independent set- } \\
\text { up times }\end{array}$ & 9 & 9 & 9 & 9 \\
\hline
\end{tabular}

With respect to the demand, a highly volume demand fluctuation can limit MRP implementations by the difficult of developing a detailed sales forecast, one of the primary inputs of MRP [36]. Consequently, the moderate variability presented in the Ecuadorian SMEs could appear as a risk for the MRP implementation. The consequences could be related to a cost incrementing resulted of the excess of inventory required to protect the planning against the demand uncertainty [39].

Other possible limitation is related to the highly volume and accuracy of the information required for managing this kind of systems. In fact, previous literature presents how the probability of success in MRP implementations varies according to the level of preparation and experience of the people in charge of the collection and processing of the required data. Consequently, a MRP implementation could imply for Ecuadorian SMEs a considerable amount of training and investment in IT systems.

One of the few points that positively influence in the MRP implementation are the sequence independence set-up times that at the Ecuadorian context contribute with the MRP principle that assumes fixed planned lead times [40]. Similarly, a low due date allowance variability is an incentive for its implementation by not requiring frequent adjustment of protective measures such as safety stocks or lead times factors that in MRP influence significantly in the achievement of the DDP [41].

Evaluating Kanban applicability in an Ecuadorian SMEs context: Traditionally Kanban has been considered an appropriate system for repetitive environments with few products and limited engineering changes [42] [43]. One 
reason is the requirement of maintaining inventory buffers at each stage of the processes for each of the products [44]. In this way, the product differentiation and the wide variety presented in the Ecuadorian SMEs could limit its application. At the product category the only positive point for Kanban is the simplicity of the products that allows a reduction in the components stock required for allowing that a customer order can be pulled along the value stream [28].

Traditionally, Kanban has been presented in the OM literature applied at the pure flow shop environment [3]. A kind of ideal situation of the reality where orders flow from one workstation to another in a deterministic manner [45]. However, it differs from the actual flow pattern at the Ecuadorian SMEs closer to a general flow shop. In this case, the lack of a strict order in the sequence of the work centers can generate complications in the Kanban implementation resulted from the difficulties for forecasting the demand and scheduling the shop [46].

Additionally, the variability presented in the Ecuadorian SMEs context can influence negatively in the performance of Kanban systems. It is based in results like the presented by Koukoumialos and Liberopoulos [47] that show how a processing times with $\mathrm{CV}^{2}$ beyond 1 reduce significantly the production capacity of a Kanban system. Similarly, the inter arrival time [26] and the volume demand variability presented in the Ecuadorian SMEs company can destroy the flow and undermine the performance of this kind of systems [48].

Similar to other traditional PPC systems, Kanban is not considered suitable for MTO environments. One of the reason is the lack of elements aimed to achieve a high DDP such as a customer enquiry stage and job entry and job release stages [3]. In fact, several cases of application present evidence of the low due date performance of Kanban in comparing with conventional shop control techniques [49]. The ow due date allowance variability presented in the Ecuadorian SMEs is an incentive for Kanban implementation by not requiring frequent adjusting of the number of cards.

Despite the numerous negative points Kanban could obtain, some benefits presented for the Ecuadorian SMEs context. For instance, the presence of sequence independent set-up times facilitates significantly Kanban by avoiding the inclusion of set-up change protocols [50]. Similarly the repetitiveness presented in this evaluation context is considered suitable for Kanban implementations [51]. Additionally, Kanban is a non-computerized system focused on the shop floor physical operations that primary utilizes visual systems instead of sophisticated software for controlling the flow of materials. Consequently, it does not require high accurate volume of information [52] reducing significantly the training requirements and minimizing the need of high skilled operators.

Evaluating WLC applicability in an Ecuadorian SMEs context: The WLC system is designed specifically for MTO environments, whereby different products are designed for different customers [17]. In fact, WLC has been presented as suitable for the large variety of products [53] required to meet increasing customer expectations in modern markets like the presented in Ecuadorian SMEs context.

At WLC systems, jobs are released to the pre-shop floor after they have been accepted by the entry stage and the materials become available [54]. Therefore, fewer components may lead to reduced task complexity. In fact, some authors such as Stevenson and Silva [55] presented empirical evidence of WLC applications in which the product complexity affects the calculation of due dates. In this way, the WLC methodology is considered highly suitable to the simple characteristic of the Ecuadorian products.

WLC addresses the dynamic circumstances of job shops. Considering its flexibility, WLC is suited to address complex situations that are typically present in real cases [56]. One of the essential elements of WLC is the control point at the release stage. According to Henrich et al. [17], once orders have been released, they should follow a simple priority rule to control their progress. This rule may be infeasible for sequencing-dependent setups, that is uncommon in the SMEs Ecuadorian context.

The information and IT requirements for implementing WLC are modest relative to those of other planning and control initiatives [57]. However, WLC requires accurate and up-to-date information on an order's progress [58]. This aspect is one of the main barriers prohibiting the successful implementation of WLC in environments like the presented in Ecuadorian SMEs characterized by sparse, out-of-date, general and centralized shop floor information. Similarly to MRP, the WLC methodology requires copious amounts of accurate data to provide feedback regarding job progress [59]. For example, WLC proposes a sequencing procedure that requires continuous information about the buffer contents issued on the CCRs [60]. Most of this information is directly determined from the shop floor and provided by shop floor personnel. Therefore, environments with unskilled operators and deficient training programs may be important barriers for a successful WLC implementation.

Evaluating $S-D B R$ applicability in an Ecuadorian SMEs context: The simplicity of the S-DBR planning based on maintaining just one buffer and the lack of a CCR's detailed scheduling makes this system a flexible option for environments with a frequent inclusion of new products [61] like the Ecuadorian SMEs context. Additionally, maintaining a protection based exclusively on time makes of S-DBR a suitable system to multi-product environments because it is not necessary maintaining expensive material safety stock for each of the products [62]. Other positive factor is the simple structure of the Ecuadorian SMEs' products that not requires numerous assembly points that could have appeared as a barrier for the S-DBR implementation [63].

With respect to the process variables, S-DBR still appears highly suitable to the Ecuadorian SMEs context. For instance, the more frequent process pattern presented in Ecuadorian SMEs is the general flow shop. This is a material flow pattern recommended for systems like S-DBR where it is necessary that the CCR states relatively stationary. Similarly the presence of sequence independent set-up times is an incentive for a S-DBR implementation considering it is a system where the order's sequencing should be constrained directly by the market [35]. In the same way considering the market as a unique constraint presents some implications with respect to the volume of the required information which is significantly reduced in comparison with other traditional PPCSs. In fact, empirical evidence presents S-DBR as a system where control can be sustained based on visual management not requiring sophisticated IT systems or high skilled labor [64] a reality in the Ecuadorian SMEs context.

With respect to the process variability, S-DBR as other TOC production system tries to minimize the complexity of 
the planning. In this way S-DBR does not matter the presence of low or moderate variability processing times like the presented in the Ecuadorian SMEs. Variability is buffered by the size of time buffers established for each of the product families [65]. Similarly low or moderate inter arrival time variability can be managed by the S-DBR mechanism that proposes the orders should be released $1 / 2$ buffer time prior the order is supposed to be worked on the CCR [66]. This mechanism stays a kind of pre-shop pool where orders await according to the release time determined by the availability of the CCR.

It is not the same case for the volume demand variability that in the Ecuadorian SMEs can be considered moderately variable. The presence of this kind of variability is still a risk because a sudden increment in the volume of certain products can generate the emerging of temporary bottlenecks [35].

Probably S-DBR is one of the PPC systems more oriented to the MTO environments [64]. Concepts like planned load that sets the due dates based on the CCR's capacity or the inclusion of systems that continuously monitor the buffer consumption of the orders make of S-DBR a system very recommendable to companies that pursue a highly DDP. However, the high due date tightness presented in the Ecuadorian SME's market could appear as a barrier for a system where the process variability is usually buffered by the increment of the offered lead times. Some cases of SDBR application in Ecuador employ capacity reservation as an option to offering DD shorter than the market standard [66]. However, it is not a suitable decision that could be generalized considering the limited capacities presented in the Ecuadorian SMEs context. Finally, a positive point for the S-DBR implementation at the Ecuadorian market is the stable allowance in the DD reflected in low variable slack times. In this way, the establishment of protective measure such as the increment of the lead times will not require frequent adjustments.

\section{DisCUSSION}

Despite several frameworks have been proposed for the selection of a PPCS, they have been very limited in the combination of qualitative and quantitative dimensions. In most of the cases, the frameworks were principally based on attributes that should be evaluated according to the subjectivity of the selector.

We also consider that certain dimensions should be analyzed necessarily in this way. However, the knowledge that the OM literature presents with respect to how different operational conditions influence on a PPCS performance makes necessary the inclusion of dimensions according a quantitative approach. For instance, our proposed framework should help to recognize that a processing time with CV over 1 could influence negatively in the proportion of backordered demands or can reduce significantly the production capacity of a Kanban system. Similarly, presenting the due date allowance as an evaluating dimension could help to determine a negative branch that could appear in a PPCS when the slack times are limited.

In order to test this combination of quantitative and qualitative measures, we apply our proposed framework to determine a suitable PPCS for Ecuadorian SMEs. Scoring each dimension according to the positive or negative correlation with respect to the Ecuadorian SMEs characteristics, it was possible to choose between four PPCSs approaches namely MRP, Kanban, WLC and S-DBR.

The framework helped in getting not only a quantitative indicator to show the level of suitability of each PPCSs with respect to the Ecuadorian SMEs characteristics. Additionally, presents the strengths or weakness of PPCSs for each of the dimensions evaluated. This information brings practical insights by providing to the practitioners a quantitative measure with respect to the opportunities that has the selected PPCS in their company. For instance, in our case even S-DBR was selected as the most suitable system to the Ecuadorian SMEs, it still presents dimensions such as the volume demand variability or the highly due date tightness with negative marks. At this case, practitioners should be conscious that if these dimensions are no handled appropriately it could jeopardize the implementation of SDBR. It is notorious that evaluating different PPCSs for the same company allows to identify the mechanism that best-fist to the characteristics of the company. In this way the framework can indicate what mechanisms or principles of the other methodologies could be incorporated to the selected PPCS in order to increase its suitability with respect to the context of implementation.

Our proposed framework has been evaluated at a general approach trying to identify the requirements of a group of companies. A future research could intent to evaluate the proposed framework as a tool that support not only the selection but also the design of PPCS according to the characteristics of a company.

\section{ACKNOWLEDGMENT}

The authors wish to acknowledge the support of the Ecuadorian SMEs that provide the necessary information for the developing of this research.

\section{REFERENCES}

[1] J. Olhager and M. Rudberg, "Linking manufacturing strategy decisions on process choice with manufacturing planning and control systems," International Journal of Production Research, vol. 40, no. 10, pp. 2335-2351, 2002.

[2] A. Tenhiala, "Contingency theory of capacity planning: The link between process types and planning methods," Journal of Operations Management, vol. 29, no. 1, pp. 65-77, 2011.

[3] M. Stevenson*, L. C. Hendry, and B. Kingsmant, "A review of production planning and control: the applicability of key concepts to the make-to-order industry," International journal of production research, vol. 43, no. 5, pp. 869-898, 2005.

[4] B. L. MacCarthy and F. C. Fernandes, "A multidimensional classification of production systems for the design and selection of production planning and control systems," Production Planning \& Control, vol. 11, no. 5, pp. 481-496, 2000.

[5] A. Kagan, K. Lau, and K. R. Nusgart, "Information system usage within small business firms," Entrepreneurship: Theory and Practice, vol. 14, no. 3, pp. 25-37, 1990.

[6] N. Towers and B. Burnes, "A composite framework of supply chain management and enterprise planning for small and medium-sized manufacturing 
enterprises," Supply Chain Management: An International Journal, vol. 13, no. 5, pp. 349-355, 2008.

[7] E. Schragenheim, H. W. Dettmer, and J. W. PATTERSON, Supply chain management at warp speed (Supply chain management at warp speed). 2009.

[8] T. G. Schmitt, T. Klastorin, and A. Shtub, "Production classification system: concepts, models and strategies," International journal of production research, vol. 23, no. 3, pp. 563-578, 1985.

[9] N. Larsen and L. Alting, "Criteria for selecting a production control philosophy," Production Planning \& Control, vol. 4, no. 1, pp. 54-68, 1993.

[10] R. A. Wysk and J. S. Smith, "A formal functional characterization of shop floor control," Computers \& industrial engineering, vol. 28, no. 3, pp. 631-643, 1995.

[11] T. E. Vollmann, W. L. Berry, and D. C. Whybark, "Manufacturing planning and control systems, 1997," Irwin, Boston, 1997.

[12] T. Hill, "Manufacturing Strategy-Text and Cases. 2000," Irvin McGrave Hill.-68c, 2000.

[13] R. H. Hayes and S. C. Wheelwright, "Restoring our competitive edge: competing through manufacturing," 1984.

[14] E. A. Silver, D. F. Pyke, and R. Peterson, Inventory management and production planning and scheduling. Wiley New York, 1998.

[15] T. E. Vollmann, W. L. Berry, D. C. Whybark, and F. R. Jacobs, Manufacturing planning and control for supply chain management. McGraw-Hill/Irwin New York, 2005.

[16] E. Gaury, H. Pierreval, and J. Kleijnen, "An evolutionary approach to select a pull system among Kanban, Conwip and Hybrid," Journal of Intelligent Manufacturing, vol. 11, no. 2, pp. 157-167, 2000.

[17] P. Henrich, M. Land, and G. Gaalman, "Exploring applicability of the workload control concept," International journal of production economics, vol. 90, no. 2, pp. 187-198, 2004.

[18] I. Tatsiopoulos and N. Mekras, "An expert system for the selection of production planning and control software packages," Production Planning \& Control, vol. 10, no. 5, pp. 414-425, 1999.

[19] A. Howard, A. Kochhar, and J. Dilworth, "Case studies based development of a rule-base for the specification of manufacturing planning and control systems," International Journal of Production Research, vol. 38, no. 12, pp. 2591-2606, 2000.

[20] D. M. Schroeder, S. W. Congden, and C. Gopinath, "Linking competitive strategy and manufacturing process technology," Journal of Management Studies, vol. 32, no. 2, pp. 163-189, 1995.

[21] J. Olhager and J. Wikner, "Production planning and control tools," Production Planning \& Control, vol. 11, no. 3, pp. 210-222, 2000.

[22] F. R. Jacobs and R. B. Chase, Operations and Supply Chain Management: The Core. McGraw-Hill Irwin, 2013.

[23] W. L. Berry and T. Hill, "Linking systems to strategy," International Journal of Operations \&
Production Management, vol. 12, no. 10, pp. 3-15, 1992.

[24] D. C. Steele, W. L. Berry, and S. N. Chapman, "Planning and Control in Multi-Cell Manufacturing," Decision sciences, vol. 26, no. 1, pp. 1-34, 1995.

[25] P. Henrich, Applicability aspects of workload control in job shop production. Labyrint Publications, 2005.

[26] A. M. Bonvik, C. Couch, and S. B. Gershwin, "A comparison of production-line control mechanisms," International journal of production research, vol. 35, no. 3, pp. 789-804, 1997.

[27] Ö. F. Baykoç and S. Erol, "Simulation modelling and analysis of a JIT production system," International Journal of Production Economics, vol. 55, no. 2, pp. 203-212, 1998.

[28] W. J. Hopp and M. L. Spearman, Factory physics. McGraw-Hill/Irwin New York, 2008.

[29] J.-H. Lee, J.-G. Chang, C.-H. Tsai, and R.-K. Li, "Research on enhancement of TOC Simplified Drum-Buffer-Rope system using novel generic procedures," Expert Systems with Applications, vol. 37, no. 5, pp. 3747-3754, 2010.

[30] M. L. Fisher and C. D. Ittner, "The impact of product variety on automobile assembly operations: Empirical evidence and simulation analysis," Management science, vol. 45, no. 6, pp. 771-786, 1999.

[31] T. E. Vollmann, W. L. Berry, and D. C. Whybark, "Manufacturing planning and control systems," Irwin, Boston, 1997.

[32] A. Kochhar and B. McGarrie, "Identification of the Requirements of Manufacturing Control Systems: A Key Charactericstics Approach," Integrated Manufacturing Systems, vol. 3, no. 4, pp. 4-15, 1992.

[33] B. MacCarthy, J. Wilson, and S. Crawford, "Human performance in industrial scheduling: a framework for understanding," Human Factors and Ergonomics in Manufacturing \& Service Industries, vol. 11, no. 4, pp. 299-320, 2001.

[34] W. G. Gilland, "A simulation study comparing performance of CONWIP and bottleneck-based release rules," Production Planning \& Control, vol. 13, no. 2, pp. 211-219, 2002.

[35] E. Schragenheim, H. W. Dettmer, and J. W. Patterson, Supply chain management at warp speed: Integrating the system from end to end. CRC Press Boca Raton, FL, 2009.

[36] J. Bertrand and D. Muntslag, "Production control in engineer-to-order firms," International Journal of Production Economics, vol. 30, pp. 3-22, 1993.

[37] Y. Chen, W.-M. Miao, Z.-Q. Lin, and G.-L. Chen, "Adjusting MRP for dynamic differentiation of identical items for process customisation," Production Planning and Control, vol. 19, no. 6, pp. 616-626, 2008.

[38] M. M. N. Mbaya, "The constraints and limitations of manufacturing resource planning (MRP II) as a tool for shop floor control," Massachusetts Institute of Technology, 2000. 
[39] J. Yeung, W. Wong, and L. Ma, "Parameters affecting the effectiveness of MRP systems: a review," International journal of production research, vol. 36, no. 2, pp. 313-332, 1998.

[40] S. L. Koh, S. M. Saad, and J. Padmore, "Development and implementation of a generic order release scheme for modelling MRP-controlled finite-capacitated manufacturing environments," International Journal of Computer Integrated Manufacturing, vol. 17, no. 6, pp. 561-576, 2004.

[41] W. Benton, "Safety stock and service levels in periodic review inventory systems," Journal of the operational research society, pp. 1087-1095, 1991.

[42] B. R. J. FINCH and J. F. Cox, "An examination of just-in-time management for the small manufacturer: with an illustration," International Journal of Production Research, vol. 24, no. 2, pp. 329-342, 1986.

[43] L. Abuhilal, G. Rabadi, and A. Sousa-Poza, "Supply Chain Inventory Control: A Comparison Among JIT, MRP, and MRP With Information Sharing Using Simulation," Engineering Management Journal, vol. 18, no. 2, 2006.

[44] B. Baynat, Y. Dallery, M. D. Mascolo, and Y. Frein, "A multi-class approximation technique for the analysis of kanban-like control systems," International Journal of Production Research, vol. 39, no. 2, pp. 307-328, 2001.

[45] W. J. Davis and S. J. STUBITZ, "Configuring a kanban system using a discrete optimization of multiple stochastic responses," International Journal of Production Research, vol. 25, no. 5, pp. 721-740, 1987.

[46] V. Gargeya and J. Thompson, "Just-in-time production in small job shops," INDUSTRIAL MANAGEMENT-CHICAGO THEN ATLANTA-, vol. 36, pp. 23-23, 1994.

[47] S. Koukoumialos and G. Liberopoulos, "An analytical method for the performance evaluation of echelon kanban control systems," in Stochastic Modeling of Manufacturing Systems: Springer, 2006, pp. 193-222.

[48] J.-L. Deleersnyder, T. J. Hodgson, H. Muller-Malek, and P. J. O'Grady, "Kanban controlled pull systems: an analytic approach," Management Science, vol. 35, no. 9, pp. 1079-1091, 1989.

[49] Z. Huq, "Conventional shop control procedures to approximate JIT inventory performance in a job shop," Journal of manufacturing systems, vol. 18, no. 3, pp. 161-174, 1999.

[50] G. N. Krieg and H. Kuhn, "Analysis of multiproduct kanban systems with state-dependent setups and lost sales," Annals of Operations Research, vol. 125, no. 1-4, pp. 141-166, 2004.

[51] M. Akturk and F. Erhun, "An overview of design and operational issues of kanban systems," International Journal of Production Research, vol. 37, no. 17, pp. 3859-3881, 1999.

[52] T.-M. Chang and Y. Yih, "Generic kanban systems for dynamic environments," THE INTERNATIONAL JOURNAL OF PRODUCTION RESEARCH, vol. 32, no. 4, pp. 889-902, 1994.
[53] M. Hoeck, "A workload control procedure for an FMC integrated in a job shop," International Journal of Computer Integrated Manufacturing, vol. 21, no. 6, pp. 666-675, 2008.

[54] M. Stevenson, "Refining a workload control (WLC) concept: a case study," International Journal of Production Research, vol. 44, no. 4, pp. 767-790, 2006.

[55] M. Stevenson and C. Silva, "Theoretical development of a workload control methodology: evidence from two case studies," International Journal of Production Research, vol. 46, no. 11, pp. 3107-3131, 2008.

[56] L. Hendry, M. Land, M. Stevenson, and G. Gaalman, "Investigating implementation issues for workload control (WLC): a comparative case study analysis," International journal of Production economics, vol. 112, no. 1, pp. 452-469, 2008.

[57] J. W. Fowler, G. L. Hogg, and S. J. Mason, "Workload control in the semiconductor industry," Production Planning \& Control, vol. 13, no. 7, pp. 568-578, 2002.

[58] H.-P. Wiendahl, Load-oriented manufacturing control. Springer, 1995.

[59] M. Stevenson and L. C. Hendry, "Aggregate loadoriented workload control: a review and a reclassification of a key approach," International Journal of Production Economics, vol. 104, no. 2, pp. 676-693, 2006.

[60] J. Riezebos, G. Korte, and M. Land, "Improving a practical DBR buffering approach using Workload Control," International Journal of Production Research, vol. 41, no. 4, pp. 699-712, 2003.

[61] E. Schragenheim, A. Weisenstern, and A. Schragenheim, "What's really new in Simplified DBR," in TOCICO international conference, Las Vegas, $N V$, 2006, vol. 32.

[62] E. Schragenheim and H. W. Dettmer, Manufacturing at warp speed: Optimizing supply chain financial performance. CRC Press, 2000.

[63] E. Schragenheim and H. W. Dettmer, "Simplified Drum-Buffer-Rope A Whole System Approach to High Velocity Manufacturing," WWW document) available, vol. 29, p. 2007, 2000.

[64] Y. J. Hwang, C.-L. Huang, and R. K. Li, "Using Simplified Drum-Buffer-Rope to Rapidly Improve Operational Performance: A Case Study in China," Production and Inventory Management Journal, vol. 47, no. 1, pp. 80-93, 20112011.

[65] E. Goldratt, "Reliable rapid response strategy and tactics tree," Goldratt's Group, 2006.

[66] E. Schragenheim, "Using SDBR in rapid response projects," Goldratt group, 2006.

17 $7_{\text {th }}$ LACEI International Multi-Conference for Engineering, Education, and Technology: "Industry, Innovation, And Infrastructure for Sustainable Cities and Communities", 24-26 July 2019, Jamaica. 